\title{
Competitive Pressures and Access to Infertility Treatments by Single Women
}

\author{
Drake Daniel Hernandez, Helen Schneider* \\ The University of Texas at Austin, Austin, TX, USA \\ Email: "h.schneider@eco.utexas.edu
}

Received 29 July 2016; accepted 21 August 2016; published 24 August 2016

Copyright (C) 2016 by authors and Scientific Research Publishing Inc.

This work is licensed under the Creative Commons Attribution International License (CC BY). http://creativecommons.org/licenses/by/4.0/

c) (i) Open Access

\begin{abstract}
With the increase in fertility problems and delayed childbearing, demand for infertility treatments has been rising. Today, in-vitro fertilization (IVF) is the most successful infertility treatment but access to IVF is uneven due to its high costs and personal and religious attitudes. To meet rising demand for infertility treatments many markets saw an increased entry of infertility clinics. This study examines the relationship between competitive pressures and access to IVF in the United States by single women. We use US data from 1995 and 2014 to show that competitive pressures improve access to infertility treatments for single women across markets and over time. Overall, this study finds that competition among IVF clinics has a beneficial effect on access to IVF.
\end{abstract}

\section{Keywords}

İfertility, In-Vitro Fertilization, The Herfindahl-Hirschman Index, Competitive Pressures, Discrimination, Access

\section{Introduction}

About 11 percent of American women between 15 and 44 years of age have difficulty getting pregnant or carrying a pregnancy to term (CDC). Today, over 1 percent of all infants born in the United States every year are conceived using assisted reproductive technologies (ART) such as in-vitro fertilization (IVF). Since IVF became available in the United States for those households that are having difficulties conceiving naturally, the procedure has drawn attention for allowing women who previously would not have been able to reproduce to have biological children. The American Society for Reproductive Medicine states unequivocally that all assisted reproduction requests should be treated equally and should not be discriminated by a person's marital or partner status:

Unmarried persons and gays and lesbians have interests in having and rearing children. There is no persuasive

"Corresponding author. 
evidence that children raised by single parents or by gays and lesbians are harmed or disadvantaged by that fact alone. Programs should treat all requests for assisted reproduction equally without regard to marital status or sexual orientation [1].

Despite this nonbinding position statement, IVF clinics in the United States do not always provide equal access to all women. While data concerning access of gay and lesbian minorities is not available, CDC does collect data on access to IVF by single women. This study examines the role of competitive pressures in improving unmarried women's access to IVF across markets and over time as more IVF clinics enter the markets.

Economic theory defines discrimination as the offering of different opportunities to similar individuals who differ only by personal characteristics such as race, gender, marital status, etc. It also predicts that mounting competitive pressures should eliminate discrimination since business owners who care only about profits are at an advantage when competing against those who also care about discrimination. As a result, clinics that do not discriminate tend to replace those that do. In this way, competitive pressures have a natural remedy for discrimination. Although previous literature does not exist on discrimination in IVF markets, there is an extensive literature on the relationship between competition and access to medical care. Overall, the evidence is mixed. On one hand, hospital consolidation that leads to more concentrated markets was found to decrease access to reproductive services [2] while on the other hand less profitable services may not be available in more competitive markets especially in for-profit hospitals [3]. Similarly, the effect of competition among hospitals on access to hospital care for uninsured patients is unclear. In some studies hospitals decrease charity care in competitive settings while other studies find no effect or worth outcomes for uninsured patients in concentrated markets [4] [5]. For example, Lee et al. (2016) find that when the uninsured Hirschman-Herfindahl Index (HHI) increased by 0.01 , the uninsured were $593 \%$ more likely to be transferred to another hospital. The study finds that when hospitals dominate the market, they tend to "expel" uninsured patients to other hospitals ([5], p. 1). Cho et al. (2016) find that as competition increases the continuity of care for children with ambulatory care-sensitive conditions also increases [6].

This study contributes to previous literature on several fronts. First, we calculate the Herfindahl-Hirschman Index (HHI) to measure market competition across Metropolitan Statistical Areas (MSAs) in the United States. Second, we estimate the effect of competitive pressures on access for single women in 1995 (the first nationally representative data set that was made available by CDC) across markets and the effect of competitive pressures over time, between 1995 and 2014 (the latest year of data that is available). Finally, we collect data on declared religious and political beliefs within each MSA and their effect on access to infertility treatments by marital status.

\section{Methods}

\subsection{Data}

We use the 1995 ART Fertility Clinic Success Rates Report. The data is publicly available from Center of Disease Control and Prevention (CDC). The unit of analysis is a clinic performing ART (no patient level data is available). Clinic-level data was collected on 43,701 ART cycles at 263 reporting clinics in the United States during 1995. By 2014 the number of ART cycles had grown to 208,786 cycles at 460 clinics.

We use ART Fertility Clinic Success Rates Report data to construct the following variables: number of IVF cycles performed by a clinic and whether a clinic works with single women. Market area characteristics came from publicly available state and MSA-level data. The Religious sentiment variable is based on the survey by the Association of Statisticians of American Religious Bodies (ASARB) that collects data on the number of adherents for 236 religious groups in each county and MSA of the United States. The variable captures the number of adherents for any religious congregation within MSA per 1000 population.

The total population at the MSA-level along with the percentage of educated populous variable is based on the current population reports from the United States Census [7]-[9]. This data is collected at the state level and captures percent of the population whose educational attainment is, at minimum, a bachelor's degree. MSAlevel income per household data is attained from the National Center for Education Statistics [10].

The political sentiment variable was calculated using data from the American Presidency Project at the University of California, Santa Barbara [11]. The mean and standard deviation of the percentage of the population which voted Republican was taken in the 1996 and 2012 presidential elections. These values were then used to gauge how conservative the state voted in the aforementioned elections. 


\subsection{Competition Index}

We use Herfindahl-Hirschman Index (HHI) to measure market competition. The index is constructed based on total non-donor fresh IVF cycles performed for each clinic. Increases in the Herfindahl index generally indicate a decrease in competition and an increase of market power, whereas decreases indicate the opposite. The index can vary from zero (perfect competition) to 10,000 (monopoly). We use the metropolitan statistical area (MSA) as the relevant market for infertility clinics in our sample.

\subsection{Statistical Analysis}

To test the effect of HHI on access to infertility treatments, two empirical models are used. First, we estimate the effect of HHI on access in 1995 and 2014 using the following probit model:

$$
\text { Access }_{i}=\beta_{0}+\beta_{1} \text { HHI }_{m}+\beta_{2} \text { Sentiment }_{m}+\beta_{3} \text { Clinic }_{i}+\beta_{4} \text { Market }_{s}+\varepsilon_{m i}
$$

Variable Access $=1$ if clinic $i$ works with single women as reported to the CDC and 0 otherwise. Coefficient $\beta_{1}$ captures the effect of market competition, coefficient $\beta_{2}$ captures religious and political sentiment, $\beta_{3}$ controls for the size of the clinic (measured by the volume of the IVF procedures). Variable Market ${ }_{s}$ is a vector of controls for variables that vary across states that might also affect the market. These include: median family income, population, and percentage of college educated population.

In our second model, we capture changes in access to IVF with the following multivariate regression model:

$$
\Delta \text { Access }_{i}=\beta_{0}+\beta_{1} \Delta \mathrm{HHI}_{m}+\beta_{2} \text { Sentiment }_{m}+\beta_{3} \Delta \text { Clinic }_{i}+\beta_{4} \Delta \text { Market }_{s}+\varepsilon_{m i}
$$

Variable $\Delta$ Access shows changes in the number of clinics that work with single women and all independent variables capture changes between 1995 and 2014. Variable $\Delta$ HHI calculates changes in competitive pressures between 1995 and 2014: increases in this variable indicate higher competitive pressures. Since most markets became more competitive, we subtracted HHI for 2014 from HHI in 1995 for each market. Other changes are measured between 2014 and 1995 to capture changes in clinic and market characteristics over time.

Finally, we reduce our sample just to clinics that did not offer IVF to single women in 1995 and examine characteristics of these clinics in 2014. Specifically, we are interested in whether clinics that started offering IVF to single women faced higher competitive pressures relative to clinics that still do not offer IVF to this population. Due to low sample size, we only use t-tests to gage significance in differences.

\section{Results}

\subsection{Descriptive Statistics}

Table 1 below presents descriptive statistics for our first model.

Table 1 shows that in 1995 about 21\% of IVF clinics in the United States did not offer IVF to single women. Also, most clinics operated in what Federal Trade Commission defines as highly concentrated markets with HHI above 2500 .

\subsection{Empirical Results}

Table 2 presents probit results.

Probit estimates in Table 2 show that both competitive pressures and religious sentiment were important factors driving access to IVF for single women. As HHI increases (i.e. as markets become less competitive) access declines. This result is consistent with economic theory that predicts competition to drive discrimination out of the market. Also, larger clinics provide better access; result is significant at $\mathrm{p}<0.11$.

Since most clinics worked with single women in 2014, probit estimates for HHI are not significant for that year alone (results table is available upon request).

In Table 3 we show factors that affect changes in the number of clinics that provide IVF services to single women.

Results above show that markets that saw larger changes in the number of clinics providing access to IVF also saw greater increases in competition. The markets also saw greater population growth and changes towards larger clinics that conduct more IVF cycles. 
Table 1. Means and standard deviations, 1995.

\begin{tabular}{ccccc}
\hline Variable & Mean & St. Deviation & Min & Max \\
\hline Access = 1 if clinic works with single women & 78.71 & 0.41 & 0 & 1 \\
HHI & 4494.85 & 3034.09 & 1381.59 & 10,000 \\
Religious sentiment & 490.56 & 93.99 & 289.13 & 970 \\
Political sentiment & 0.466 & 0.232 & 0.0000678 & 0.951 \\
Total IVF cycles & 166.16 & 212.16 & 7 & 2272 \\
Household income & $51,161.23$ & 7816.83 & $33,631.18$ & $69,682.48$ \\
Education & 20.58 & 3.74 & 12.33 & 33.31 \\
Population & $3,358,452$ & $4,713,672$ & 96,119 & $1.96 \mathrm{e}+07$ \\
\hline
\end{tabular}

Note: Number of IVF clinics is 263.

Table 2. Probit Results for the Access to IVF by Single Women, 1995.

\begin{tabular}{cc}
\hline Variable & Access \\
\hline HHI & $-0.000139^{* * * *}(0.0000386)$ \\
Religious sentiment & $-0.00321^{* *}(0.00126)$ \\
Political sentiment & $-0.452(0.502)$ \\
Total IVF cycles & $0.00135(0.000854)$ \\
Household income & $6.14 \mathrm{e}-06(0.0000238)$ \\
Education & $0.045(0.0488)$ \\
Population & $-2.52 \mathrm{e}-08(3.05 \mathrm{e}-08)$ \\
$\mathrm{N}$ & 259 \\
Chi-squared & $49.62^{* * *}$ \\
\hline
\end{tabular}

Note: standard errors are in parentheses. ${ }^{*} \mathrm{p}<0.10,{ }^{* *} \mathrm{p}<0.05,{ }^{* * *} \mathrm{p}<0.01$.

Table 3. Linear regression for change in access to IVF for single women from 1995 to 2014.

\begin{tabular}{cc}
\hline Variable & Access \\
\hline Changes in HHI & $0.0002604^{* * *}(0.00007)$ \\
Religious sentiment & $0.0001543(0.0033376)$ \\
Changes in political sentiment & $1.32694(1.019003)$ \\
Changes in total IVF cycles & $0.009502^{* * *}(0.0000572)$ \\
Changes in household income & $-0.0001746^{* *}(0.0000704)$ \\
Changes in education & $-0.3464836^{* *}(0.1378621)$ \\
Changes in population & $6.65 \mathrm{e}^{-0} 7^{* * *}(2.37 \mathrm{e}-07)$ \\
$\mathrm{N}$ & 100 \\
R-squared & 0.8253 \\
\hline
\end{tabular}

Note: standard errors are in parentheses. ${ }^{*} \mathrm{p}<0.10,{ }^{* *} \mathrm{p}<0.05,{ }^{* * *} \mathrm{p}<0.01$.

Finally, we reduce our sample to just 16 clinics that did not provide IVF to single women and still operated in 2014. Of these 16 clinics only 2 still did not accept single women in 2014.

Results in Table 4 show that clinics that started offering IVF to single women between 1995 and 2014 saw higher changes in HHI and thus faced higher competitive pressures than clinics that still denied access to IVF 
Table 4. Changes in access to IVF by single women, 1995-2014.

\begin{tabular}{ccc}
\hline Variable & Access $=0$ in $2014(\mathrm{n}=2)$ & Access $=1$ in $2014(\mathrm{n}=14)$ \\
\hline Changes in HHI & $1343.42(1254.34)$ & $1480.004(2383.114)$ \\
Religious sentiment & $607.705(7.38)$ & $553.3807(136.30)$ \\
Changes in political sentiment & $0.0401(0.107)$ & $-0.0106(0.229)$ \\
Changes in total IVF cycles & $90(149.91)$ & $231.29(255.702)$ \\
Changes in household income & $1704.96(872.15)$ & $1241.91(2069.81)$ \\
Changes in education & $5.62(0.996)$ & $7.65(1.65)$ \\
Changes in population & $158,064(310,934.7)$ & $513,132.9(718,158.8)$ \\
\hline
\end{tabular}

for single women. These differences were not statistically significant. One-tail t-test was only statistically significant for the education variable: clinics that started offering IVF to single women were located in areas that saw higher changes in proportion of the population earning their college degrees $(\mathrm{p}<0.0583)$.

\section{Discussion}

\subsection{Conclusion and Policy Implications}

Results of this study are consistent with prevailing economic theory and previous literature on competition: competitive pressures can decrease discrimination and improve access [2] [6]. For example, empirical estimates show that access to infertility services for single women has greatly improved over time. Competitive pressures contributed significantly to this improvement. Nevertheless, even in 2014 data we see uneven access in some areas. While entry has enhanced access for many single women who want to pursue infertility treatments, some markets will remain concentrated due to lower population density and may be defined as natural monopolies with one clinic being able to provide IVF services to the entire market area. In such markets access barriers may persist. Also, competitive markets can only solve discrimination when it comes from producers. When customers discriminate, e.g. households prefer to be treated in clinics that do not serve single women or gay households, the access will remain limited.

\subsection{Limitations of the Study and Avenues for Future Research}

An important limitation of this study is the absence of data on access to IVF treatments by gay and lesbian households. Thus, we are not able to separate discrimination based on marital status from discrimination based on sexual preference. Note that until 2003 when the Massachusetts Supreme Judicial court legalized gay marriage, it was illegal in all fifty states. Also, while attitudes towards single motherhood did not change significantly since 1995, attitudes towards the gay and lesbian community have changed [12] and may have contributed greatly to better access for all unmarried women that we see in the data. Finally, gay marriage was legalized in 2015 and became law in all states. On one hand, this change may improve access for lesbian women who were not able to marry in the past and enhance access in areas where barriers for married women existed to prevent access to infertility services for that group. On the other hand, the gay community may still face barriers to infertility treatments even after legalization of gay marriage. Examining the effect of the legalization of samesex marriage on access to medical care and infertility treatments in particular is an important avenue for future research.

\section{Acknowledgements}

The authors are grateful to the School of Undergraduate Studies for the funding for this project as well as anonymous referees for their helpful comments.

\section{References}

[1] American Society for Reproductive Medicine (2016) LGBT and Unmarried Persons Reproductive Rights. https://www.asrm.org/topics/detail.aspx?id=504 
[2] Bellandi, D. (1998) Access Declines. Reproductive Services Fall with Hospital Consolidation. Modern Healthcare, 28, 26.

[3] Schlesinger, M., Dorwart, R., Hoover, C. and Epstein, S. (1997) Competition, Ownership, and Access to Hospital Services. Evidence from Psychiatric Hospitals. Medical Care, 35, 974-992. http://dx.doi.org/10.1097/00005650-199709000-00009

[4] Schneider, H. and Yilmaz, H. (2013) Hospital Community Benefits and the Effect of Schedule H: A Difference-in-Difference Approach. Health, 5, 1681-1688. http://dx.doi.org/10.4236/health.2013.510226

[5] Lee, K.H., Lim, S. and Park, J.E. (2016) Expelled Uninsured Patients in a Less-Competitive Hospital Market in Florida, USA. International Journal of Equity Health, 15, 85. http://dx.doi.org/10.1186/s12939-016-0375-Z

[6] Cho, K., Park, E., Nam, Y., Lee, S., Nam, C. and Lee, S. (2016) Impact of Market Competition on Continuity of Care and Hospital Admissions for Asthmatic Children: A Longitudinal Analysis of Nationwide Health Insurance Data 20092013. PLoS ONE, 11, 1-13. http://dx.doi.org/10.1371/journal.pone.0150926

[7] United States Census (2016) Educational Attainment in the United States: 2015. http://www.census.gov/content/dam/Census/library/publications/2016/demo/p20-578.pdf

[8] United States Census (2016) 2015 Population Estimates. American Fact Finder. http://factfinder.census.gov/faces/tableservices/jsf/pages/productview.xhtml?src=bkmk

[9] United States Census (2003) Population in Metropolitan and Micropolitan Statistical Areas in Alphabetical Order and Numerical and Percent Change for the United States and Puerto Rico: 1990 and 2000. United States Census 2000. https://www.census.gov/population/www/cen2000/briefs/phc-t29/tables/tab01a.pdf

[10] National Center for Education Statistics (2010) Median Household Income, by State: Selected Years, 1990 through 2009. Digest of Education Statistcs. https://nces.ed.gov/programs/digest/d10/tables/dt10_025.asp

[11] Wolley, J. and Peters, G. (2016) Presidential Selection. The American Presidency Project. http://www.presidency.ucsb.edu/showelection.php?year=1992

[12] Pew Research Center (2013) Changing Attitudes on Same Sex Marriage, Gay Friends and Family. http://www.people-press.org/2013/06/06/changing-attitudes-on-same-sex-marriage-gay-friends-and-family/

\section{Submit or recommend next manuscript to SCIRP and we will provide best service for you:}

Accepting pre-submission inquiries through Email, Facebook, LinkedIn, Twitter, etc.

A wide selection of journals (inclusive of 9 subjects, more than 200 journals)

Providing 24-hour high-quality service

User-friendly online submission system

Fair and swift peer-review system

Efficient typesetting and proofreading procedure

Display of the result of downloads and visits, as well as the number of cited articles

Maximum dissemination of your research work

Submit your manuscript at: http://papersubmission.scirp.org/ 